\title{
A STUDY ON MECHANIZATION OF AERATION IN TURFGRASS
}

\author{
H. A. FOUAD*, S. H. DESOKY**, R. A. WERBY**, H. A. A. SAYED***
}

\begin{abstract}
The objective of the present work was to develop and evaluate aeration machine for turfgrass to make under Egyptian condition. The aeration machine was evaluated versus two holes density (24 and $48 \mathrm{hole} / \mathrm{m}^{2}$ ), two hollow tine diameters $(2.5$ and $3 \mathrm{~cm})$, three average depths of aeration (4, 6 and $8 \mathrm{~cm})$ and four forward speeds (2, 2.7, 3.6 and $4 \mathrm{~km} / \mathrm{h})$. After 7 days from aeration operation the results showed that the lower bulk density and penetration resistance values was $0.960 \mathrm{~g} / \mathrm{cm}^{3}$ and $154 \mathrm{kPa}$, respectivaly opposite it the higher porosity and void ratio values were $65.09 \%$ and 1.865 , respectively at 48 hole $/ \mathrm{m}^{2}$ holes density, $3 \mathrm{~cm}$ tine diameter, $8 \mathrm{~cm}$ depth of hole and forward speed $2 \mathrm{~km} / \mathrm{h}$ comparing with control $1.271 \mathrm{~g} / \mathrm{cm}^{3}, 337 \mathrm{kPa}, 53.79 \%$ and 1.164 for density, penetration resistance, porosity and void ratio, respectively. The higher actual field capacity was $(0.941 \mathrm{fed} / \mathrm{h})$ at 24 hole/m ${ }^{2}$ holes density, $2.5 \mathrm{~cm}$ tine diameter, $4 \mathrm{~cm}$ depth of hole and forward speed $4 \mathrm{~km} / \mathrm{h}$. The lower energy required was $16.223 \mathrm{kw} . \mathrm{h} / \mathrm{fed}$, at 24 hole $/ \mathrm{m}^{2}$ holes density, $2.5 \mathrm{~cm}$ tine diameter, $4 \mathrm{~cm}$ depth of hole and forward speed $4 \mathrm{~km} / \mathrm{h}$.
\end{abstract}

\section{INTRODUCTION}

urfgrass in golf courses, clubs, public garden and stadiums play a
vital role in population life. Turfgrass refines the atmosphere from
the bad particles which cause pollution in the air (Morad et al., 2003). Turfgrass plants are normally perennial which grow through tillering, stolon and rhizomatous growth, and ideally, develop new vegetative shoots continually throughout the year. Cool-season turfgrass grow strongly in winter. Warm-season perennial grasses are growing in summer to autumn (Lodge $\boldsymbol{e t}$ al., 1990). Traffic of machine and human usually compacts the top 5 to $7.5 \mathrm{~cm}$ in turf situations with the top $2.5 \mathrm{~cm}$

\footnotetext{
*Prof. Emt. of Agric. power and mach. Eng. Dept., Faculty of Agric. Eng., Al-Azhar Univ.

${ }^{* *}$ Assoc. prof. of Agric. power and mach. Eng. Dept., Faculty of Agric. Eng., Al-Azhar Univ. ***Demons. of Agric. power and mach. Eng. Dept., Faculty of Agric. Eng.,. Al-Azhar Univ. This study is a part of outcomes from (MSc thesis).
} 
being the most severely compacted. Thatch is accumulation of living and dead grass leaves, stems and organic debris between the soil surface and the green vegetation in a turf (Beard, 1973). Excessive thatch can lead to increase disease incidence, reduce tolerance to environmental stress, and water management difficulties (Fontanier et al., 2011). Soil compaction decreased stand uniformity and plant growth, restricted root growth, reduced soil aeration, reduced water infiltration, reduced internal drainage and reduced effectiveness of underground drainage systems (Larson $\boldsymbol{e t}$ al., 1994). There are many proposed benefits of aeration including increased air-filled space, decreased compaction, increased infiltration and drainage, increased root growth, improving the application of fertilizer (Binns, 2001). Aeration is a cultivation method in which small holes are made in the soil, usually by removal of small cylinders or plugs of soil and turf. These plugs are pulled out with hollow tines, spoons, or screws, discharged on the surface and then either removed or be broken up and worked back into the turf (Pessarakli, 2007). Core size varies from $(0.635$ to $2.54 \mathrm{~cm})$ in diameter and the vertical length of the cores is usually $(7.62 \mathrm{~cm}$ ) (Turgeon, 2002). Mechanical aeration reduced bulk density and penetration resistance comparing to control (no aeration) (Abrougui et al., 2012). The hydraulic conductivity increased after mechanical aeration (Abrougui et al., 2012). Soil compaction may increase soil strength and compacted soil layers can effect on root and shoot growth. Root growth is generally noted down into the holes created by coring and coring promotes deep rooting of warm season grasses in particular (Zontek, 2002).

\section{MATERIAL AND METODS}

The aeration machine was manufactured at workshop and the experiment was carried out at Farm located in Nafesha village, Ismailia Governorate, Egypt from 2014 - 2015.

\section{Soil and turfgrass:}

The mechanical analysis of soil was classified as sandy and the real soil density is $2.75 \mathrm{~g} / \mathrm{cm}^{3}$ and turfgrass type was Paspalum.

\section{The aeration machine of turfgrass:}

The aeration machine Figures (1 and 2) is constructed of main frame, hitching system, flanges, shaft, bearing and core tines. The overall 
dimension of aeration machine were $117 * 63.5 * 86 \mathrm{~cm}$. The distance between each flange was $8 \mathrm{~cm}$. The distance between centers of two consecutive core tines was $125 \mathrm{~cm}$. The total weight of aeration machine was $255 \mathrm{~kg}$. Each flange has sex core tines based on it and each core tine fixed by two bolts and nuts.

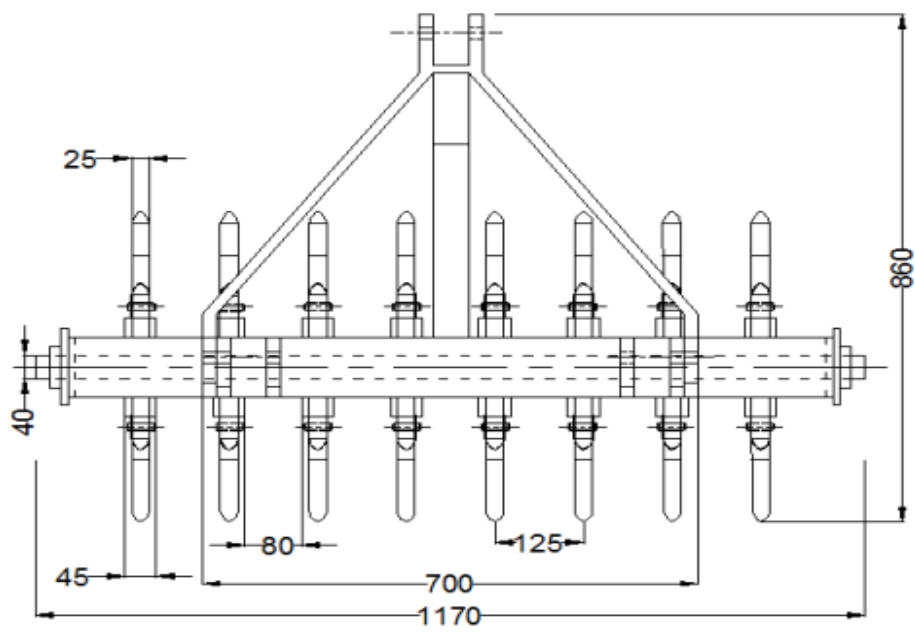

Fig. (1): Elevation of aeration machine.

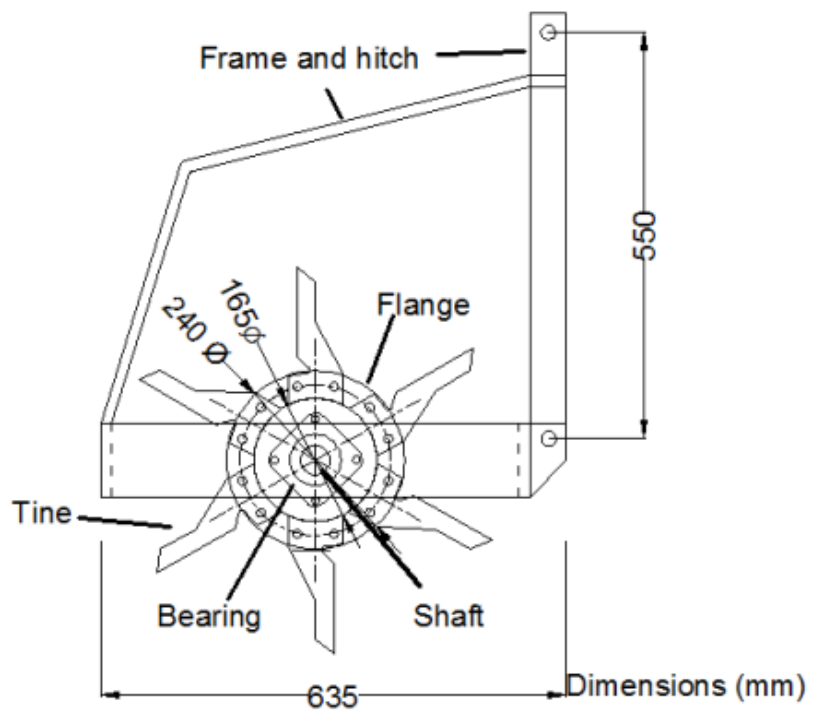

Fig. (2): Side view of aeration machine.

The flange had two diameters the big diameter is $240 \mathrm{~mm}$ with thickness $25 \mathrm{~mm}$ and the small diameter is $165 \mathrm{~mm}$ with thickness $45 \mathrm{~mm}$. The shaft was manufactured from medium carbon steel, $117 \mathrm{~cm}$ length and 4 cm diameter. 


\section{Source of power:}

The characteristics of the agricultural tractor are driving wheel $2 \mathrm{WD}$, engine power $33 \mathrm{hp}(24.6 \mathrm{~kW})$ at $2700 \mathrm{rpm}$ and source of manufacture is Japan.

\section{Soil bulk density:}

Soil samples were taken with cylindrical core $\left(100 \mathrm{~cm}^{3}\right.$ volume). The core samples were immediately weighted and then they were dried at $105 \mathrm{C}^{\circ}$ for 24 hours. Soil bulk density was determined according the following formula:

$$
\rho_{b}=\frac{W_{d}}{T_{v}}
$$

Where:

$\rho_{\mathrm{b}}$ : Soil bulk density, $\mathrm{g} / \mathrm{cm}^{3}$.

$\mathrm{W}_{\mathrm{d}}$ : Dry soil mass, $\mathrm{g}$.

$\mathrm{T}_{\mathrm{v}}$ : Total soil volume, $\mathrm{cm}^{3}$.

\section{Soil porosity:}

Soil porosity was determined by using the following formula:

$$
\mathbf{S}_{\mathbf{p}}=\left\{1-\left(\frac{\rho_{\mathbf{b}}}{\rho_{\mathbf{s}}}\right)\right\} * 100
$$

Where:

$\mathrm{S}_{\mathrm{p}}$ : Soil porosity $(\%)$.

$\rho_{\mathrm{s}}$ : Real soil density, $\mathrm{g} / \mathrm{cm}^{3}$.

\section{Void ratio:}

Void ratio (e) was calculated using the following formula:

\section{Penetration resistance:}

$$
\mathbf{e}=\frac{\rho_{\mathrm{s}}-\rho_{\mathrm{b}}}{\rho_{\mathrm{b}}}
$$

Soil resistance to insertion of penetrometer was determined by using the following formula:

Where:

$$
\mathrm{PR}(\mathrm{kPa})=\frac{\mathrm{F} * 9.81}{\mathrm{~A} * 10^{3}}
$$

PR: Penetration resistance, $\mathrm{kPa}$.

F: Force required to penetration, kg.

A: Average cone area, $\mathrm{m}^{2}$. 


\section{Actual field capacity:}

Actual field capacity was calculated by using the following formula:

$$
A_{\text {fc }}=\frac{1}{T_{t}}
$$

Where:

$\mathrm{A}_{\mathrm{fc}}$ : Actual field capacity, fed/h.

$\mathrm{T}_{\mathrm{t}}$ : Total effective operating time, $\mathrm{h} / \mathrm{fed}$.

\section{Energy requirements:}

The following formula was used to estimate the engine power required according to Embaby (1985):

$$
\mathrm{EP}=\text { f. } c\left(\frac{1}{3600}\right) \rho_{\mathrm{f}} * \text { L. C. } \mathrm{V} * 427 * \eta_{\mathrm{th}} * \eta_{\mathrm{m}} * \frac{1}{75} * \frac{1}{1.36}
$$

Where:

EP: Engine power, $\mathrm{kW}$.

f.c: Fuel consumption, L/h.

$\rho_{\mathrm{f}}$ : Density of fuel, $0.85 \mathrm{~kg} / \mathrm{L}$ for diesel.

L.C.V: Lower calorific value of fuel, $10000 \mathrm{kcal} / \mathrm{kg}$ for diesel.

427: Thermo-mechanical equivalent, $\mathrm{kg} . \mathrm{m} / \mathrm{kcal}$.

$\eta_{\mathrm{th}}$ : Thermal efficiency of engine, $80 \%$ for diesel.

$\eta_{\mathrm{m}}$ : mechanical efficiency of engine, $35 \%$ for diesel.

The energy requirements were calculated by using the following equation:

$$
\mathbf{E R}=\frac{\mathbf{E P}}{\mathbf{A}_{\mathrm{fc}}}
$$

Where:

ER: Energy requirements, kW.h/fed.

\section{RESULTS AND DISCUSSION}

\section{Effect of forward speed on soil bulk density:}

Results show that the values of bulk density were decreased by using aeration machine in all treatments comparing with the control (no aeration treatment). Figure (3) shows that the lower value of bulk density was $\left(0.960 \mathrm{~g} / \mathrm{cm}^{3}\right)$ at $48 \mathrm{hole} / \mathrm{m}^{2}$ holes density, $3 \mathrm{~cm}$ tine diameter, $8 \mathrm{~cm}$ depth and forward speed $2 \mathrm{~km} / \mathrm{h}$. Bulk density at 24 hole $/ \mathrm{m}^{2}$ holes density, 2.5 $\mathrm{cm}$ tine diameter, $4 \mathrm{~cm}$ depth and forward speed $4 \mathrm{~km} / \mathrm{h}$ was higher value of bulk density $\left(1.136 \mathrm{~g} / \mathrm{cm}^{3}\right)$, comparing with the control $\left(1.271 \mathrm{~g} / \mathrm{cm}^{3}\right)$. 
The bulk density values decreased with decreasing forward speed and increasing (holes density, tine diameter and depth of hole).

Tine diameter, $3 \mathrm{~cm}$

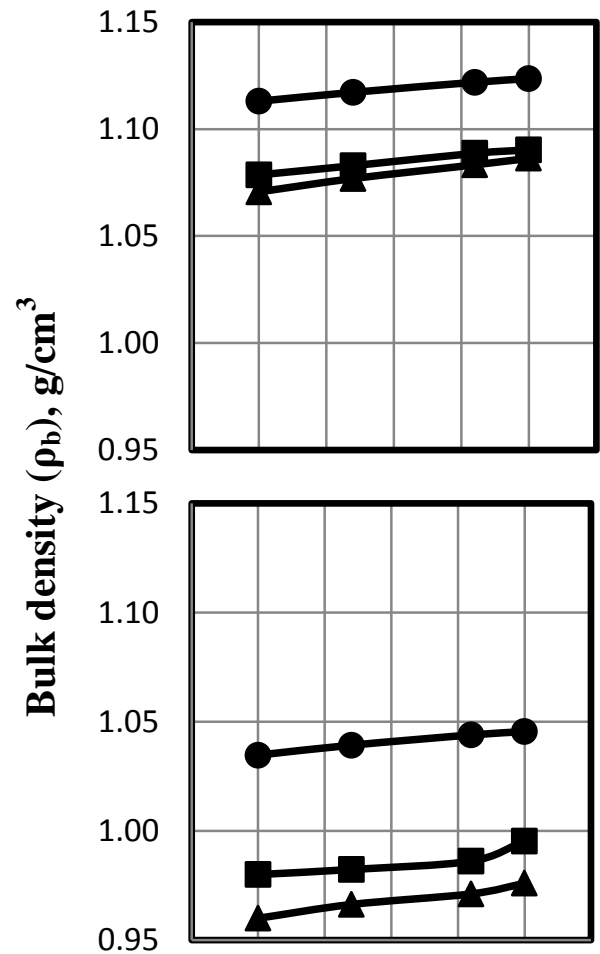

$\begin{array}{lllllll}1.5 & 2 & 2.5 & 3 & 3.5 & 4 & 4.5\end{array}$
Tine diameter, $2.5 \mathrm{~cm}$
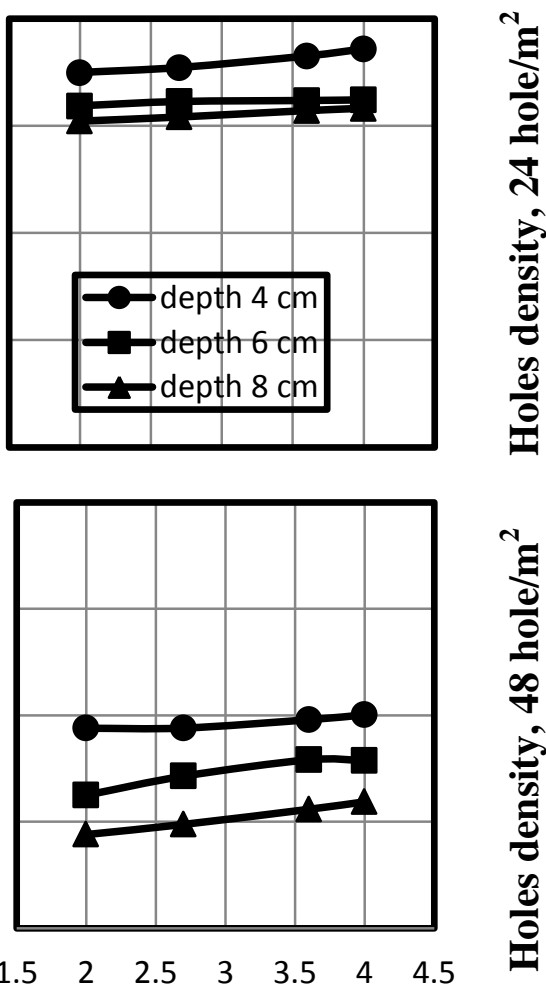

Forward speed (FS), km/h

Fig. (3): Bulk density Vs forward speed during different holes density, tine diameter and depth of holes after 7 days from aeration.

\section{Effect of forward speed on soil porosity:}

Results show that the values of porosity were increased by using aeration machine in all treatments comparing with the control (no aeration treatment). Figure (4) shows that the higher value of porosity was (65.09 $\%)$ at 48 hole $/ \mathrm{m}^{2}$ holes density, $3 \mathrm{~cm}$ tine diameter, $8 \mathrm{~cm}$ depth and forward speed $2 \mathrm{~km} / \mathrm{h}$. porosity at $24 \mathrm{hole} / \mathrm{m}^{2}$ holes density, $2.5 \mathrm{~cm}$ tine diameter, $4 \mathrm{~cm}$ depth and forward speed $4 \mathrm{~km} / \mathrm{h}$ was lower value of porosity (58.69\%), comparing with the control (53.79\%). The porosity values increased with decreasing forward speed and increasing (holes density, tine diameter and depth of hole). 
Tine diameter, $3 \mathrm{~cm}$

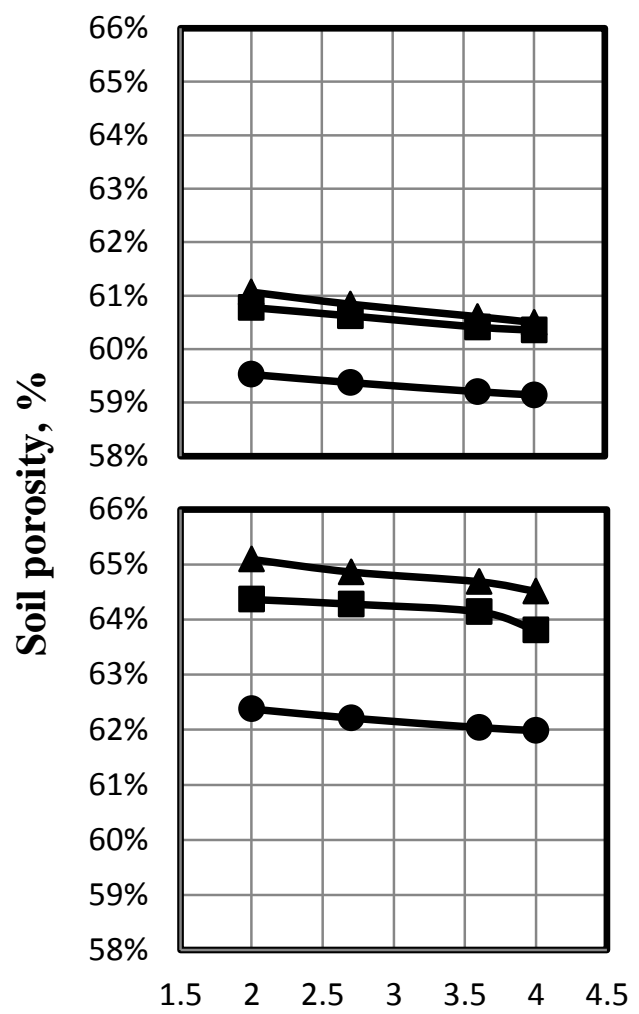

Tine diameter, $2.5 \mathrm{~cm}$
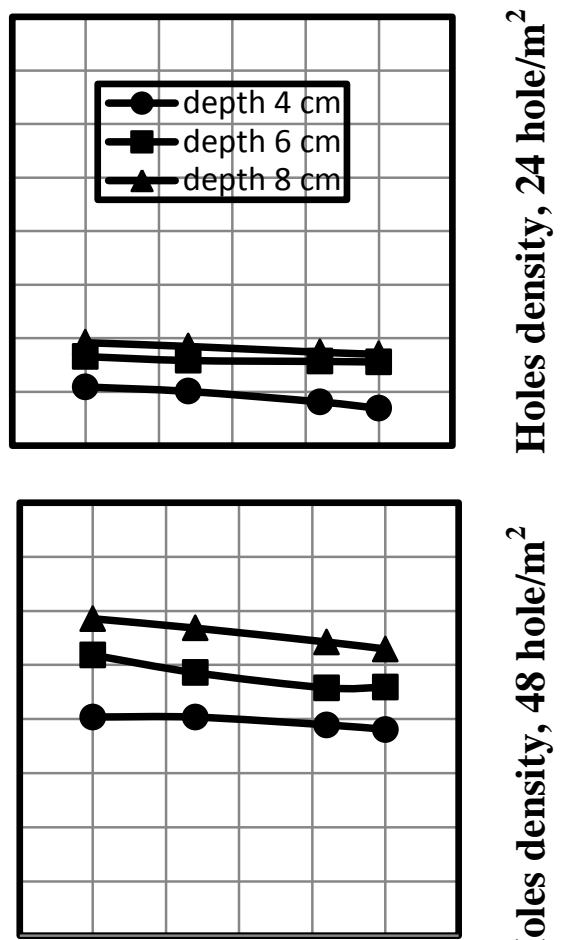

$\begin{array}{lllllll}1.5 & 2 & 2.5 & 3 & 3.5 & 4 & 4.5\end{array}$

Forward speed (FS), km/h

Fig. (4): Porosity Vs forward speed during different holes density, tine diameter and depth of holes after 7 days from aeration.

\section{Effect of forward speed on void ratio:}

Results show that the values of void ratio were increased by using aeration machine in all treatments comparing with the control (no aeration treatment). Figure (5) shows that the higher value of void ratio was (1.865) at $48 \mathrm{hole} / \mathrm{m}^{2}$ holes density, $3 \mathrm{~cm}$ tine diameter, $8 \mathrm{~cm}$ depth and forward speed $2 \mathrm{~km} / \mathrm{h}$. Void ratio at $24 \mathrm{hole} / \mathrm{m}^{2}$ holes density, $2.5 \mathrm{~cm}$ tine diameter, $4 \mathrm{~cm}$ depth and forward speed $4 \mathrm{~km} / \mathrm{h}$ was lower value of void ratio (1.421), comparing with the control (1.164). The void ratio values increased with decreasing forward speed and increasing (holes density, tine diameter and depth of hole). 
Tine diameter, $3 \mathrm{~cm}$

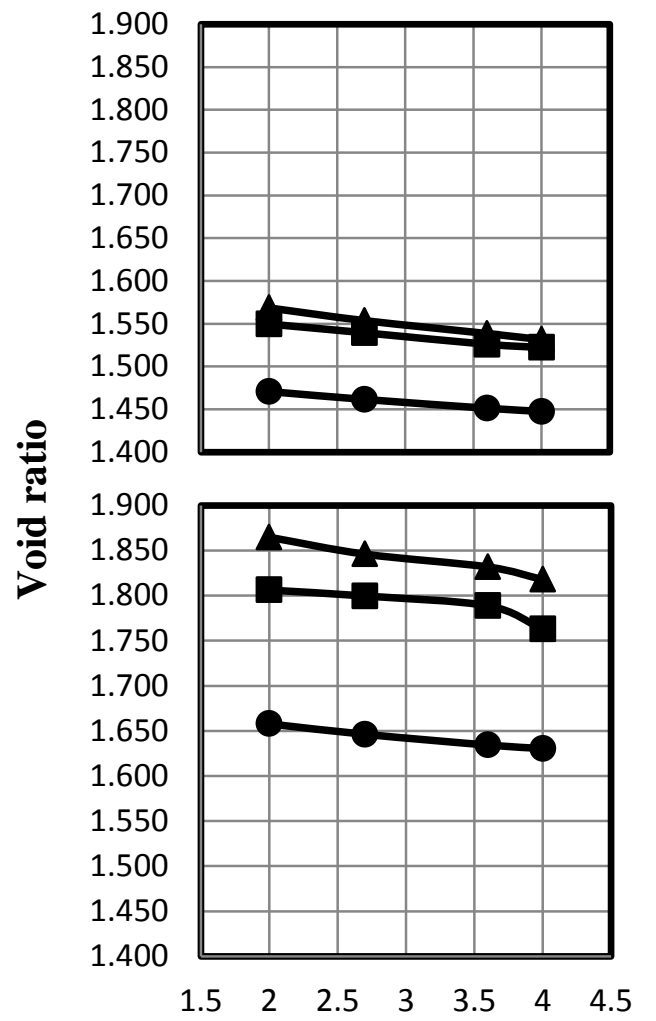

Tine diameter, $2.5 \mathrm{~cm}$
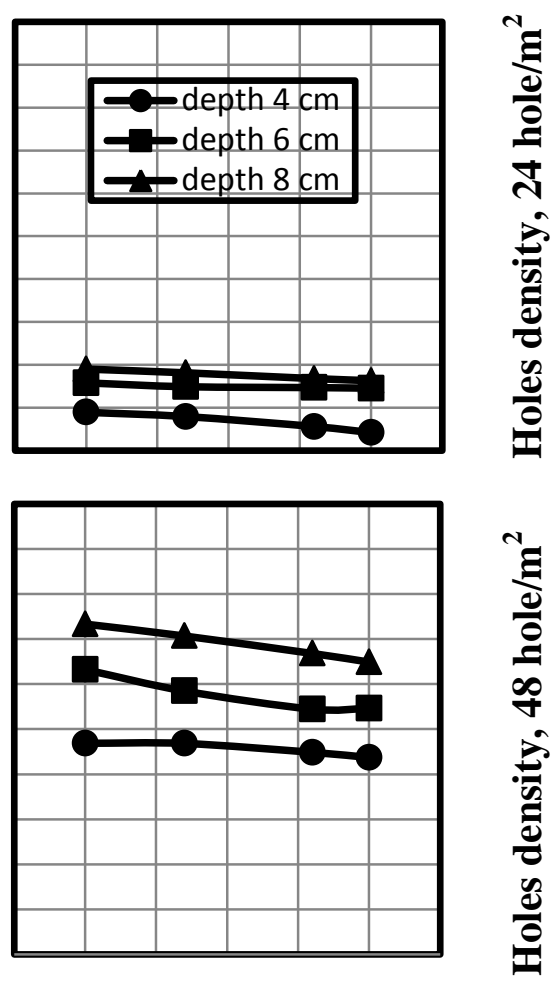

Forward speed (FS), $\mathbf{k m} / \mathbf{h}$

Fig. (5): Void ratio Vs forward speed during different holes density, tine diameter and depth of holes after 7 days from aeration.

\section{Effect of forward speed on penetration resistance:}

Results show that the values of penetration resistance were decreased by using aeration machine in all treatments comparing with the control (no aeration treatment). Figure (6) shows that the lower value of penetration resistance was $(154 \mathrm{kPa})$ at $48 \mathrm{hole} / \mathrm{m}^{2}$ holes density, $3 \mathrm{~cm}$ tine diameter, $8 \mathrm{~cm}$ depth and forward speed $2 \mathrm{~km} / \mathrm{h}$. Penetration resistance at 24 hole $/ \mathrm{m}^{2}$ holes density, $2.5 \mathrm{~cm}$ tine diameter, $4 \mathrm{~cm}$ depth and forward speed $4 \mathrm{~km} / \mathrm{h}$ was higher value of penetration resistance $(237 \mathrm{kPa})$, comparing with the control $(337 \mathrm{kPa})$. The penetration resistance values decreased with decreasing forward speed and increasing (holes density, tine diameter and depth of hole). 
Tine diameter, $3 \mathrm{~cm}$

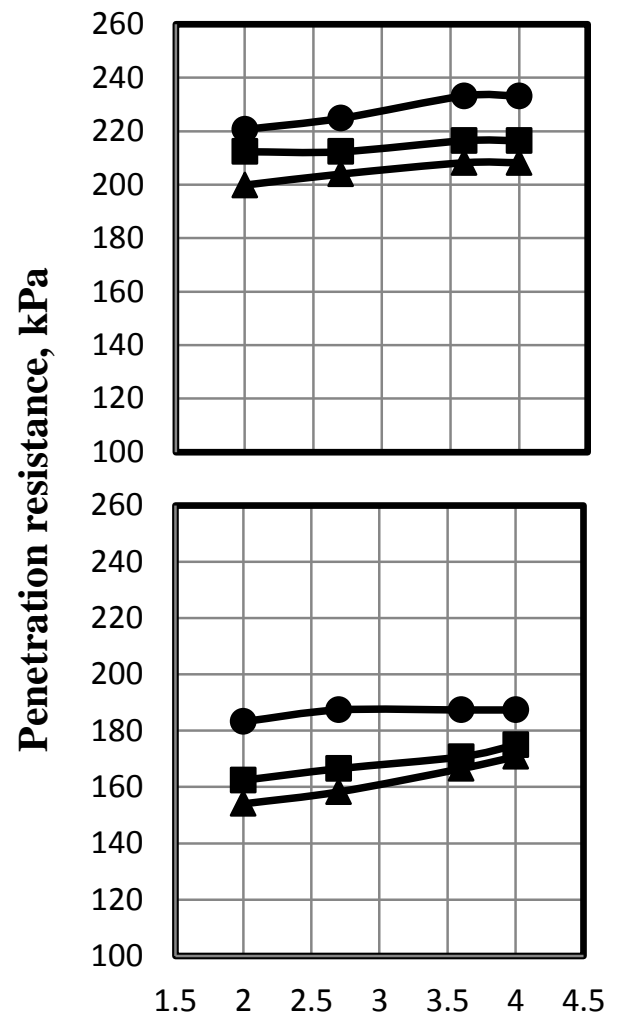

Tine diameter, $2.5 \mathrm{~cm}$
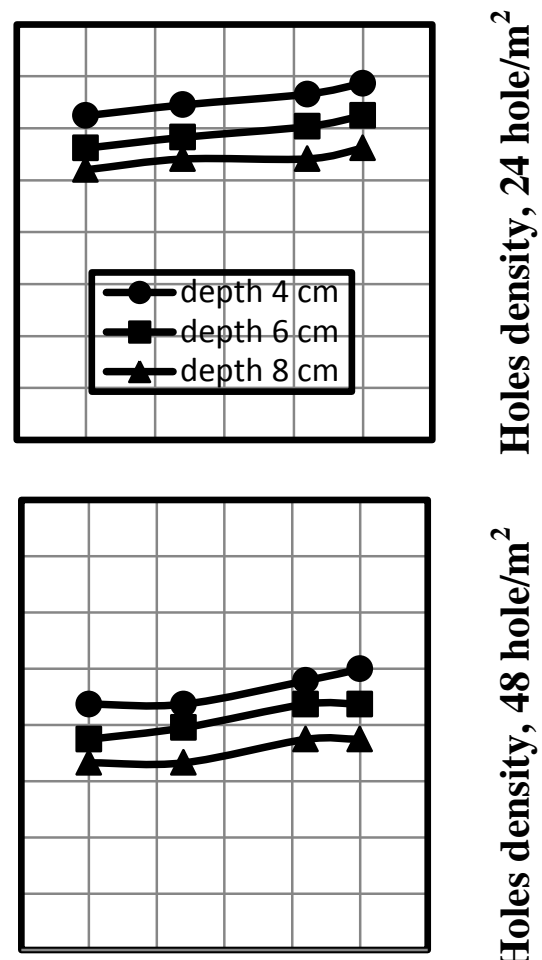

ב⿱宀

Forward speed (FS), km/h

Fig. (6): Penetration resistance Vs forward speed during different holes density, tine diameter and depth of holes after 7 days from aeration.

\section{Effect of forward speed on actual field capacity:}

Figure (7) shows that the higher value of actual field capacity was (0.941 $\mathrm{fed} / \mathrm{h}$ ) at 24 hole $/ \mathrm{m}^{2}$ holes density, $2.5 \mathrm{~cm}$ tine diameter, $4 \mathrm{~cm}$ depth and forward speed $4 \mathrm{~km} / \mathrm{h}$. Actual field capacity at $48 \mathrm{hole} / \mathrm{m}^{2}$ holes density, 3 $\mathrm{cm}$ tine diameter, $8 \mathrm{~cm}$ depth and forward speed $2 \mathrm{~km} / \mathrm{h}$ was lower value of actual field capacity $(0.449 \mathrm{fed} / \mathrm{h})$. The actual field capacity values increased with increasing forward speed and decreasing (holes density, tine diameter and depth of hole). 


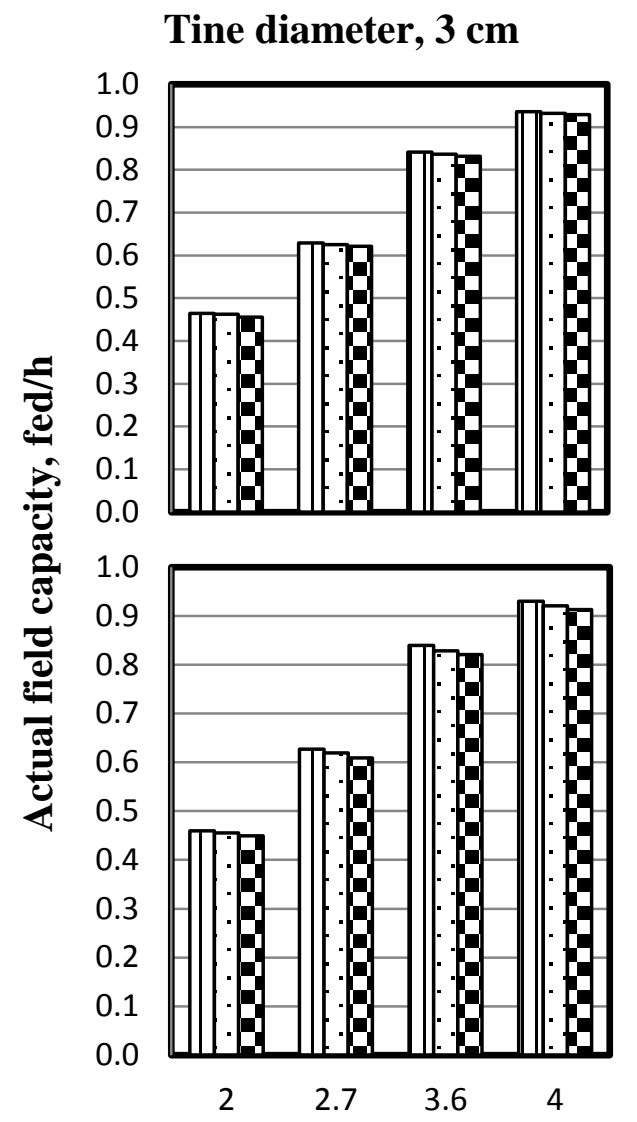

Tine diameter, $2.5 \mathrm{~cm}$
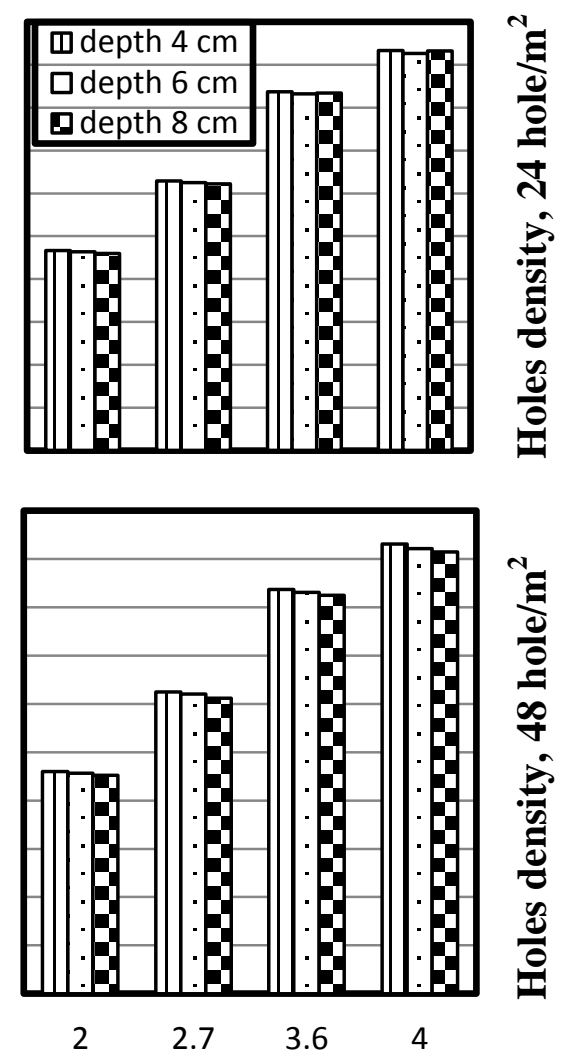

Forward speed (FS), km/h

Fig. (7): Actual field capacity Vs forward speed during different holes density, tine diameter and depth of holes after 7 days from aeration.

\section{Effect of forward speed on energy requirements:}

Figure (8) shows that the lower value of energy requirements was (16.223 $\mathrm{kW} . \mathrm{h} / \mathrm{fed}$ ) at $24 \mathrm{hole} / \mathrm{m}^{2}$ holes density, $2.5 \mathrm{~cm}$ tine diameter, $4 \mathrm{~cm}$ depth and forward speed $4 \mathrm{~km} / \mathrm{h}$. Energy requirements at $48 \mathrm{hole} / \mathrm{m}^{2}$ holes density, $3 \mathrm{~cm}$ tine diameter, $8 \mathrm{~cm}$ depth and forward speed $2 \mathrm{~km} / \mathrm{h}$ was higher value of energy requirements $(27.935 \mathrm{~kW} . \mathrm{h} / \mathrm{fed})$. The energy requirements values decreased with increasing forward speed and decreasing (holes density, tine diameter and depth of hole). 
Tine diameter, $3 \mathrm{~cm}$

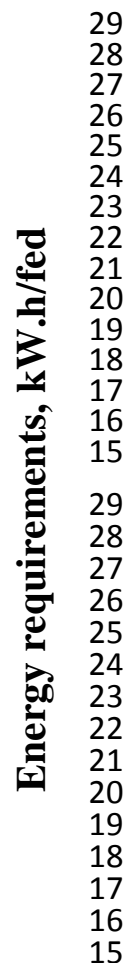

Tine diameter, $2.5 \mathrm{~cm}$
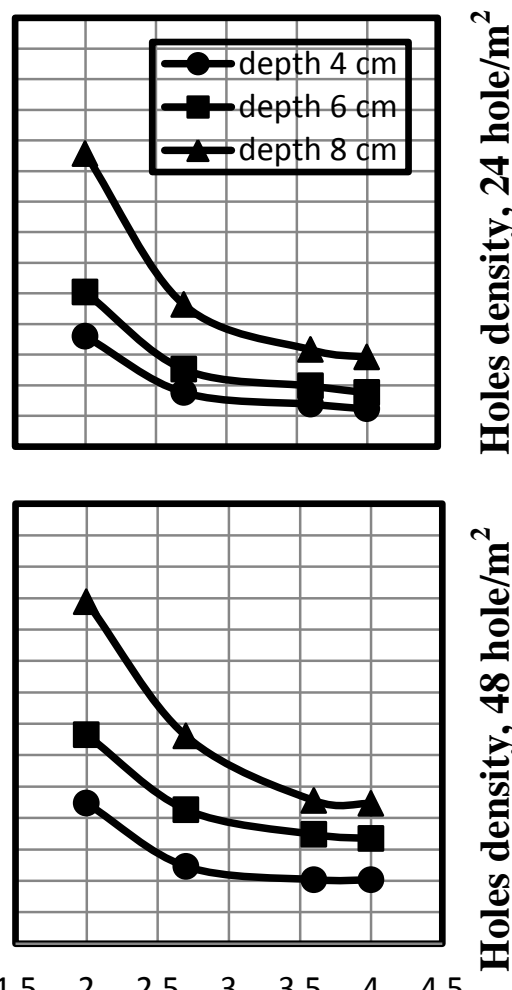

Forward speed (FS), km/h

Fig. (8): Energy requirements Vs forward speed during different holes density, tine diameter and depth of holes after 7 days from aeration.

\section{CONCLUSION}

- The lower value of bulk density and penetration resistance were $0.960 \mathrm{~g} / \mathrm{cm}^{3}$ and $154 \mathrm{kPa}$, respectively at $48 \mathrm{hole} / \mathrm{m}^{2}$ holes density, $3 \mathrm{~cm}$ tine diameter, $8 \mathrm{~cm}$ depth and forward speed $2 \mathrm{~km} / \mathrm{h}$ comparing with control $1.271 \mathrm{~g} / \mathrm{cm}^{3}$ and $337 \mathrm{kPa}$.

- The higher porosity and void ratio was $65.09 \%$ and 1.865 respectively at 48 hole $/ \mathrm{m}^{2}$ holes density, $3 \mathrm{~cm}$ tine diameter, $8 \mathrm{~cm}$ depth and forward speed $2 \mathrm{~km} / \mathrm{h}$ comparing with control $53.79 \%$ and 1.164 . 
- The higher actual field capacity was $(0.941 \mathrm{fed} / \mathrm{h})$ at $24 \mathrm{hole} / \mathrm{m}^{2}$ holes density, $2.5 \mathrm{~cm}$ tine diameter, $4 \mathrm{~cm}$ depth and forward speed 4 $\mathrm{km} / \mathrm{h}$.

- The lower value of energy consumption was $(16.223 \mathrm{~kW} . \mathrm{h} / \mathrm{fed})$ at 24 hole $/ \mathrm{m}^{2}$ holes density, $2.5 \mathrm{~cm}$ tine diameter, $4 \mathrm{~cm}$ depth and forward speed $4 \mathrm{~km} / \mathrm{h}$.

\section{REFRENCES}

Abrougui, K.; S., Chehaibi; and M., Khelifi (2012). Impact of Mechanical Aeration on the Soil Resistance to Penetration and Density of Grassy Sward. Journal of Environmental Sciences and Engineering, A1:683-687.

Beard, J.B. (1973). Turfgrass science and culture. Prentice-Hall Inc. Englewood cliffs, New Jersey. USA, P:658.

Binns, D.J. (2001). Aeration-Essential disruption. Turfgrass Bulletin, 211:9-12.

Embaby, A.T. (1985). A comparison of the different mechanization system for career crop production. Master of science thesis, agriculture engineering department, Faculty of agriculture, Cairo University.

Fontanier, C.H.; K., Steinke; J.C., Thomas; and R.H., White (2011). Effects of venting aeration on neglected bermudagrass putting greens. Applied Turfgrass Science., ATS-2011-1201-01-RS.

Larson, W.E.; A., Eynard; A., Hadas; and J., Lipiec (1994). Control and avoidance of soil compaction in practice. Soil compaction in crop production, P:597-625.

Lodge, G.M.; G.G., Robinson; and P.C., Simpson (1990). Grassesnative and naturalized value, distribution. Agfact., P:25-32.

Morad, M.M.; U.A., Kadour; and M.K., Afify (2003). Fabrication and manufacturing of a sod cutting machine. The 11th Annual Conference of the Society of the Ag. Eng 15-16 October:394-397. 
Pessarakli, M. (2007). Hand Book of Turfgrass Management and Physiology. CRC Press, Taylor and Francis Group, P:141,143,135,136.

Zontek, S.J. (2002). So similar yet so different - golf course management in the UK and the USA. International Turfgrass Bulletin, P:11-13.

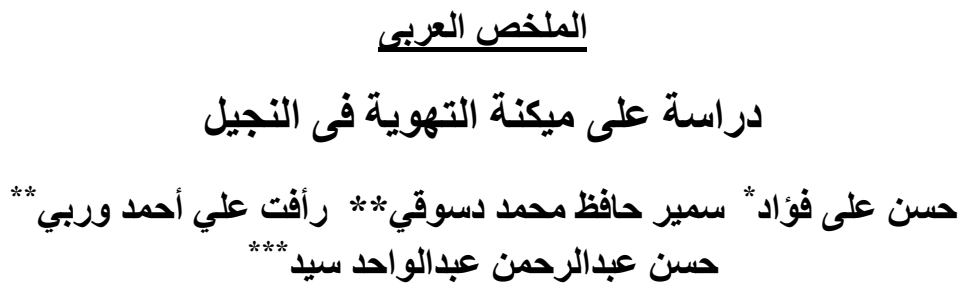

زيادة المسطحات الخضراء من أساسيات الدول المتقدمة وقد زاد الإهتمام بها فى السنوات

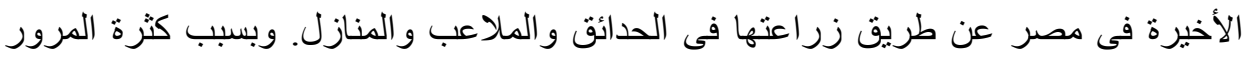

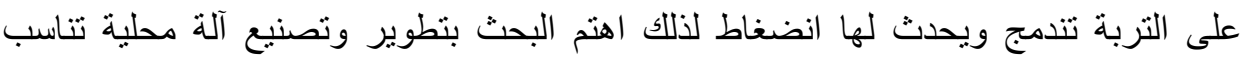

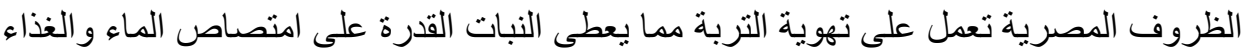

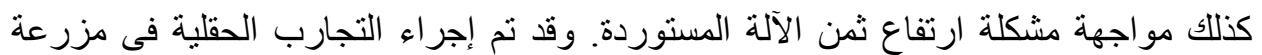

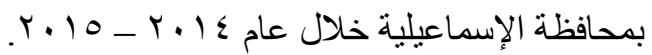

$$
\begin{aligned}
& \text { وقد تم اختبار الآلة باستخدام: }
\end{aligned}
$$

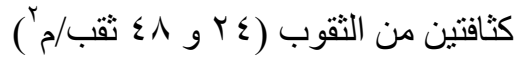

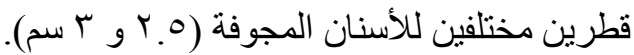

$$
\begin{aligned}
& \text { ثلاثة أعماق مختلفة للتهوية ( ( ، } 7 \text { و و } 1 \text { سم). }
\end{aligned}
$$

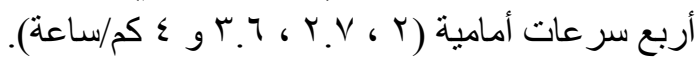

وكاتت أهم النتائج المتحصل عليها:

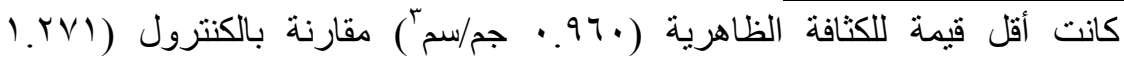

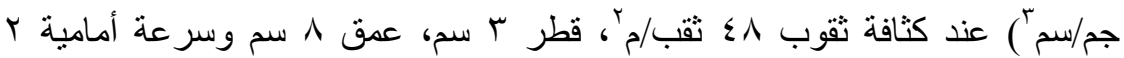
كم/ساعة.

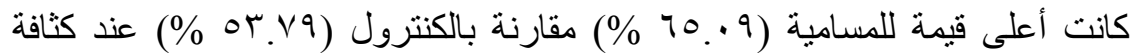

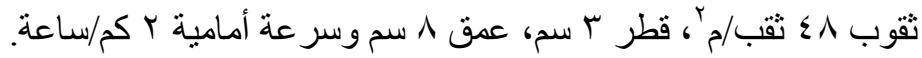

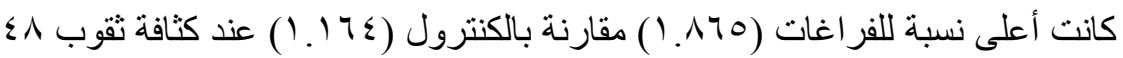

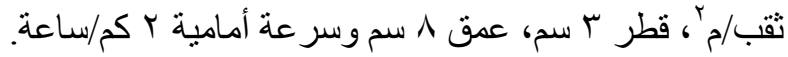

* أستاذ الآلات والقوى الزراعية المتفرغ ـ كلية الهندسة الزراعية ـ جامعة الأزهر ــ القاهرة.

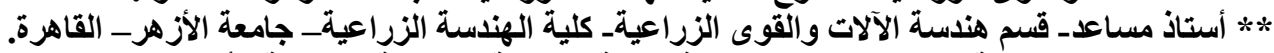

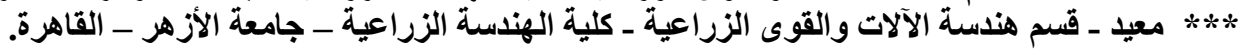




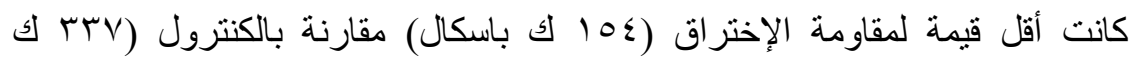

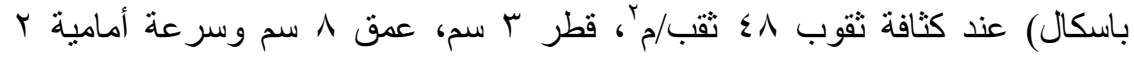
كم/ساعة.

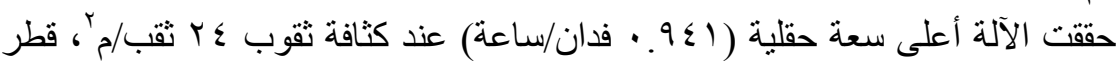

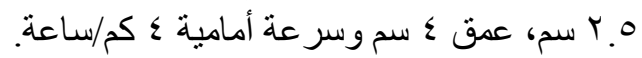

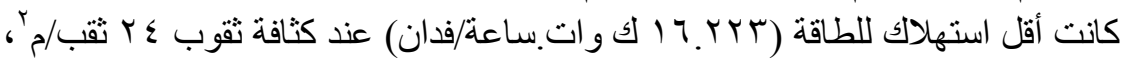
قطر ه.r سم، عمق گ سم وسرعة أمامية ؟ كم/ساعة.

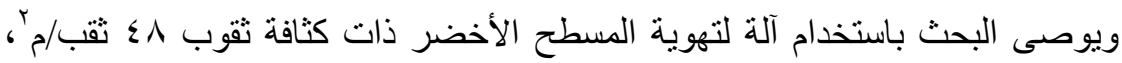

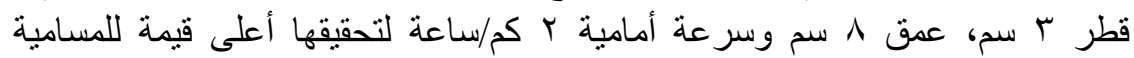
و الفر اغات وكذلك أقل قيمة للكثافة ومقاومة الإختراق. 